\title{
Organizational Learning Culture, Consumer Satisfaction and Employee's Attitude: Causality Analysis
}

\author{
Audia Junita ${ }^{\bowtie}$ \\ Management Department, STIE Harapan, Medan, Indonesia
}

\begin{tabular}{l} 
Info Article \\
\hline History Article: \\
Received November 2016 \\
Approved Januari 2017 \\
Published Maret 2017 \\
\hline Keywords: \\
Organizational Learning Culture; \\
Employee Attitude; Job Satisfac- \\
tion; Organizational Commit- \\
ment; Customer Satisfaction
\end{tabular}

\begin{abstract}
This research was conducted to explore the organizational learning culture in banking and its effect on customer satisfaction with the employee's attitude as the intervening variable. The research was performed in Bank Syariah Mandiri's business unit of Medan Region. The research design used hypothesis testing. The samples of this research were 52 frontline employees and 140 customers of Bank Syariah Mandiri in Medan Region. Primary data was collected by using a questionnaire. The data were analyzed using path analysis. Results support that Bank Syariah Mandiri as State-owned enterprises in the field of financial services has implemented good organizational learning culture. Organizational learning culture has significant effect to customer satisfaction through employee's job satisfaction and organizational commitment. The attitudes of employees are integrated important intervening variables in mediating the relationship between organizational learning culture and customer satisfaction. The role of attitude in mediating the influence of organizational learning culture to worker's service behavior, in order to create consumer satisfaction in the banking sector, proven empirically.
\end{abstract}

\section{Kultur Pembelajaran Organisasional, Kepuasan Konsumen dan Sikap Karyawan: Analisis Kausalitas}

\begin{abstract}
Abstrak
Penelitian ini dilakukan untuk mengeksplorasi kultur pembelajaran organisasional di perbankan dan pengaruhnya terhadap kepuasan pelanggan dengan sikap karyawan sebagai variabel antara. Penelitian dilakukan di unit bisnis Bank Syariah Mandiri wilayah Medan. Desain penelitian menggunakan uji hipotesis. Sampel penelitian ini adalah karyawan lini depan sebanyak 52 responden dan 140 pelanggan Bank Syariah Mandiri di wilayah Medan. Data primer dikumpulkan dengan menggunakan kuesioner. Data dianalisis menggunakan analisis jalur. Hasil penelitian membuktikan bahwa Bank Syariah Mandiri sebagai badan usaha milik negara di bidang jasa keuangan memiliki kultur pembelajaran organisasi yang baik. Kultur pembelajaran organisasi berpengaruh signifikan terhadap kepuasan konsumen melalui kepuasan kerja karyawan dan komitmen organisasi. Sikap karyawan merupakan variabel antara penting yang terintegrasi dalam memediasi hubungan antara kultur pembelajaran organisasional dan kepuasan pelanggan. Peran sikap dalam memediasi budaya pembelajaran organisasi pada kepuasan pelanggan di sektor perbankan telag terbukti secara empiris
\end{abstract}

JEL Classification: M3, M31 
Audia Junita / Organizational Learning Culture, Consumer Satisfaction, and...

\section{INTRODUCTION}

Currently, the future is dominated by a society that is able to manage the learning. Technological change and globalization are two interactive power that triggers a surge towards knowledge era (Marsick, 1998). Demands in order to make the organization more flexible in anticipating a variety of changes, making the idea of organizational learning are becoming increasingly popular nowadays. The learning organization concept becomes a strategic concept due to concern with issues about market share, productivity, quality, and profitability, to build on the success of the organization.

Learning in the context of organizational is important to be conditioned into a culture because it will significantly contribute to the continuous improvement of an organization, facilitate efficient adaptation to the challenging environment (Cunningham \& Gerard, 2000), the transformation itself (Watkins \& Marsick, 1997) and expand the capacity to shape its own future (Senge, 1990). The ability to learn to adapt to the changing environment in a sustainable way, became the driving force and organization strategies to adapt and survive in an increasingly strong market competition (Namwong et al., 2015)

In fact, the concept of learning ranging from personal to organizational. Learning is needed for the individual and also the growth of the organization. Previous empirical studies proves that the organizational learning culture contribution to individuals, which are able to trigger the appearance of participation in organizational decision-making (Thompson, 2000), willingness and awareness to do learning activity in a work environment intentionally (Park, 2011), critical thinking skills (Sabri et al., 2015).

Psychological impacts include job satisfaction and organizational commitment (Wang, 2005; Dirani, 2007; Hsu, 2009; Malik \& Danish, 2010; Islam et al., 2014), work engagement (Hsu, 2009; Malik \& Danish, 2010), readiness of individual emotional over organizational change (Miller, 2015), employee's turnover intention (Islam et al., 2013) and internal service quality (Xie, 2005).

As for the organization, organizational learning culture is capable of bringing up organizational performance (Fuentes, 2008; Cho, 2009; Coats, 2015), innovativeness (Bates \& Khasawneh, 2005; Lin, 2006; Cerne et al., 2012; Sabir \& Kalyar, 2013) and customer satisfaction ( Pantouvakis \& Bouranta, 2013; Islam et al., 2014a; Malike, 2016).

In the context of strategic marketing, organizations are required to focus on the internal and external aspect of organizations, namely, the workers who are in the organization (internal consumers) and the customers who directly use the results of the organization's product of either the goods and/or services (external consumer) (Fecikova, 2004).

Competitive advantage occurs when a superior organization over its competitors in retaining customers and position themselves to take advantage of changes in the environment (Porter, 1985). Business organizations are required to understand and be able to design and implement policies that are oriented on the emergence of a positive working attitude in employees which is able to increase consumer retention and profitability of the organization (Yang-Lim, 2004).

An organizational learning culture is a complex phenomenon and multilevel in many ways affect organizational performance (Coats, 2015). Differences in workers' perceptions towards organizational culture will have an impact on differences in employee attitudes and behaviors in serving customers, and then affect performance achievement of an organization. Therefore, the ability to manage organizational human resources well will have an impact on services quality provided to customers.

Empirical studies conducted in a service environment confirms that job satisfaction represents individual assessment over a variety of things that exist in the work environment, the results will come out in the form of emotional response. If the individual has a positive app- 
raisal of various aspects of the work environment then the emotional response will appear in the form of organizational commitment.

The result of the organizational commitment is a coping with the intention to achieve the desired results, which are working hard to give service effort in order to satisfy the need or desire of consumers (Testa, 2001) (Figure 1). Employees who have a high commitment to service quality (Xie, 2005) will be influenced to customer's satisfaction and loyalty (Heskett et al., 1994).

\begin{tabular}{|c|c|c|}
$\begin{array}{c}\text { Evaluation } \\
\text { Process }\end{array}$ & $\begin{array}{c}\text { Emotional } \\
\text { Response }\end{array}$ & $\begin{array}{c}\text { Effort } \\
\text { Intention }\end{array}$ \\
\hline $\begin{array}{c}\text { Job } \\
\text { Satisfaction }\end{array}$ & $\begin{array}{c}\text { Organizational } \\
\text { Commitment }\end{array}$ & $\begin{array}{c}\text { Service } \\
\text { Efforts }\end{array}$ \\
\hline
\end{tabular}

Figure 1. A Conceptual Model of the Relationship between Job Satisfaction, Organizational Commitment and the Service Efforts

Similarly, in banking, the significant role of banking to the national economy makes banking efforts to improve performance as well as its competitiveness, absolutely done. As profitoriented financial institutions resting their activities on service quality delivery and consumer satisfaction (Coskun \& Frohlich, 1992), must have the readiness to constantly learn and cultivate a learning culture among members of the organization (Harris, 2002).

An organizational learning culture is expected to be a much-needed banking character at this time. The efforts of banking organizations to institutionalize learning within the organization was able to increase the survival of banking in facing crises (Holland, 2010) and achieve superior financial performance compared to its competitors (Goh \& Ryan, 2008; Santoso, 2011). As a service oriented organization, to anticipate the possibility of changing the external environment, banking organizational needs to transform itself to become a learner.

The market in banking industry requires a more humanized banking face with service as a banking competitive advantage (Coskun \& Frohlich, 1992; Blanchard \& Galloway, 1994). Various researchers in retail banking institutions especially in Indonesia prove the same thing, that service is the main contributor of banking performance (Misbach et al., 2013; Sakapurnama \& Kusumastuti, 2013; Toelle, 2006).

Explorative study of determinative factors of service quality in the banking industry proves that the competence of front-line banking workers in maintaining personal relationships with customers has a significant effect on consumer perceptions of service quality (Gounaris et al., 2003), consumer satisfaction and loyalty (Heskett et al. 1997) which will then lead to the achievement of the organization's financial targets.

\section{Hypothesis Development}

Organizational Learning Culture and Employee's Job Satisfaction

From empirical studies that have been done, in general it can be concluded that the organizational learning culture research and its effect on organizational performance, more use of internal performance measures that is involving the perception of member's organization and financial data, but very rarely use external assessor such as consumers, which is the most objective parties to give judgement on service quality provided by the organization.

Cho (2009) recommends to do studies on organizational learning culture by research design that relies on objective measures and combines a range of organizational variables as a mediator or moderator, in the relationship between the learning culture and organizational performance (Schein, 1996), to provide a comprehensive picture related with models of organizational learning.

Even, empirical studies prove there are close correlation and significant influence organizational learning culture towards consumer satisfaction (Islam et al., 2014a; Malike, 2016), but according to (Coats, 2015), organizational learning culture variable is not granted directly able to affect organizational performance. In 
Audia Junita / Organizational Learning Culture, Consumer Satisfaction, and...

fact, the study of the organizational learning culture is a complex phenomenon and multilevel in many ways to influence organizational performance.

A conceptual model of the relationship between job satisfaction, organizational commitment, and service efforts which are expressed by (Testa, 2001), need to be supported by empirical foundation specifically to capture phenomena that occur in the banking sphere. The competitive advantage of banks is also determined not only by capital and technology aspects but human banking resources.

Service is the competitive edge in banking. Customer service plays a pivotal role in the development of service quality (Coskun \& Frohlich, 1992). While the quality of external service value is determined by employee satisfaction. Satisfied workers will have high levels of retention and work productivity in providing services to customers. Finally, customer satisfaction and loyalty will emerge, leading to the company's ability to achieve better profitability (Schlesinger \& Heskett, 1991; Heskett et al., 1994; Heskett et al., 1997).

Empirical studies ever since which test the influence of organizational learning culture towards consumer satisfaction only involves employee job satisfaction variable (Pantouvakis \& Bouranta, 2013). Previous research results prove that organizational culture research that is part of the organization's intellectual assets are still limited to do although they give a significant influence on the achievement of banking performance (Santoso, 2011).

The attractiveness of this study lies in testing worker attitudes variables as intervening variables in the relationship between organizational learning culture and customer satisfaction, especially in banking. That empirical and theoretical grounding become the significance of this research, to test the complexity of organizational learning culture influence toward consumer satisfaction by involving integrated employee's attitude variables, including job satisfaction and organizational commitment in the banking sector, which so far has never been done.
The study was conducted at Bank Syariah Mandiri (BSM) as a subsidiary of Bank Mandiri, one of the State-Owned Enterprises (SOEs) in the financial services sector, having the best performance in terms of customer service and satisfaction as well as good organizational governance practices (Good Corporate Governance). It is assumed that the achievement of service quality and customer satisfaction cannot be separated from the organizational learning culture that has been going on in BSM. It is what we want to review more deeply, through this research.

In the context of an internal organization, the organizational learning culture serves as an adhesive between the individual and the organization in achieving common goals and presumably can increase the activity of learning and competence of member's organization (Freiling \& Fichtner, 2010). Organizational culture is the "heart" of organization's human resources management strategy because of the effect on employee attitudes and outcomes such as retention, satisfaction, commitment, performance and other aspects (Harris \& Mossholder, 1996).

Theoretically and empirically, the attitudes of the employee include job satisfaction (Lund, 2003) and organizational commitment (Chaundry \& Shah, 2007) are formed as a result of the positive perception over organization's learning culture which is well conditioned by the organization.

The results of empirical studies prove that organizational learning culture influences significantly to employee's job satisfaction (Wang, 2005; Hsu, 2009; Pantouvakis \& Bouranta, 2013). Based on this, then the first hypothesis is formulated as follows:

$\mathrm{H1}$ : Organizational learning culture affects significantly to employee's job satisfaction.

\section{Organizational Learning Culture, Employee's Job Satisfaction, and Organizational Commitment}

The organizational learning culture also has a significant effect on the emergence of organizational commitment (Hsu, 2009; Joo \& Park, 2010; Islam et al., 2014a). Various empi- 
rical studies prove there is a close link between employee job satisfaction and organizational commitment. Job satisfaction is a result of the cognitive process, affective and evaluative to the job situation while the organizational commitment reflects the attitude of the individual's loyalty towards the organization and the process through which an individual expresses his concern to the organization that will be lead to the success of organizations (Luthans, 2011).

Job satisfaction of employees is identified as an important mediator in the relationship between organizational commitment and learning culture ( Wang, 2005; Dirani, 2007; Hsu, 2009; Islam et al., 2014b). Based on empirical studies, then the second hypothesis is formulated as follows:

$\mathrm{H} 2$ : Organizational learning culture and job satisfaction affect significantly to the organizational commitment

\section{Organizational Learning Culture, Employee's} Job Satisfaction, and Consumer Satisfaction

In the context of an external organization, the close relationship between organizational learning culture towards employee's job satisfaction and consumer satisfaction is validated empirically (Maalik \& Khan, 2011; Tanisah \& Maftuhah, 2015; Malike, 2016). Aspects of consumer satisfaction were strongly influenced by the interaction between employees and customers. Satisfied employees will tend to be more productive, provide better service to customers ( Schlesinger \& Heskett, 1991; Heskett et al., 1997; Vilares \& Coelho, 2003; Snipes et al., 2005). However, empirically also gives the diverse view.

Study of Kermani (2013) proves there is a positive relationship between employee satisfaction and customer satisfaction, while Barnes (2015) proves there is no relationship between job satisfaction and customer satisfaction. Related to the organization's learning culture, it is identified that the organizational learning culture and employee's job satisfaction influence significantly to consumer satisfaction (Pantouvakis \& Bouranta, 2013; Schulte et al., 2009; Permana, 2013). Based on that several studies, then the third hypothesis are formulated as follows:

H3: Organizational learning culture and job satisfaction of employees affect significantly to consumer satisfaction

\section{Employee's Organizational Commitment and Consumer Satisfaction}

The results of empirical studies related to the relationship between employee's organizational commitments to consumer satisfaction give the results vary. The absence of the significant relationship between the two is concluded by (Cirone, 2003). However, He et al. (2011), Islam et al. (2014a), Murale et al. (2015), Utami \& Wartini (2015) prove that organizational

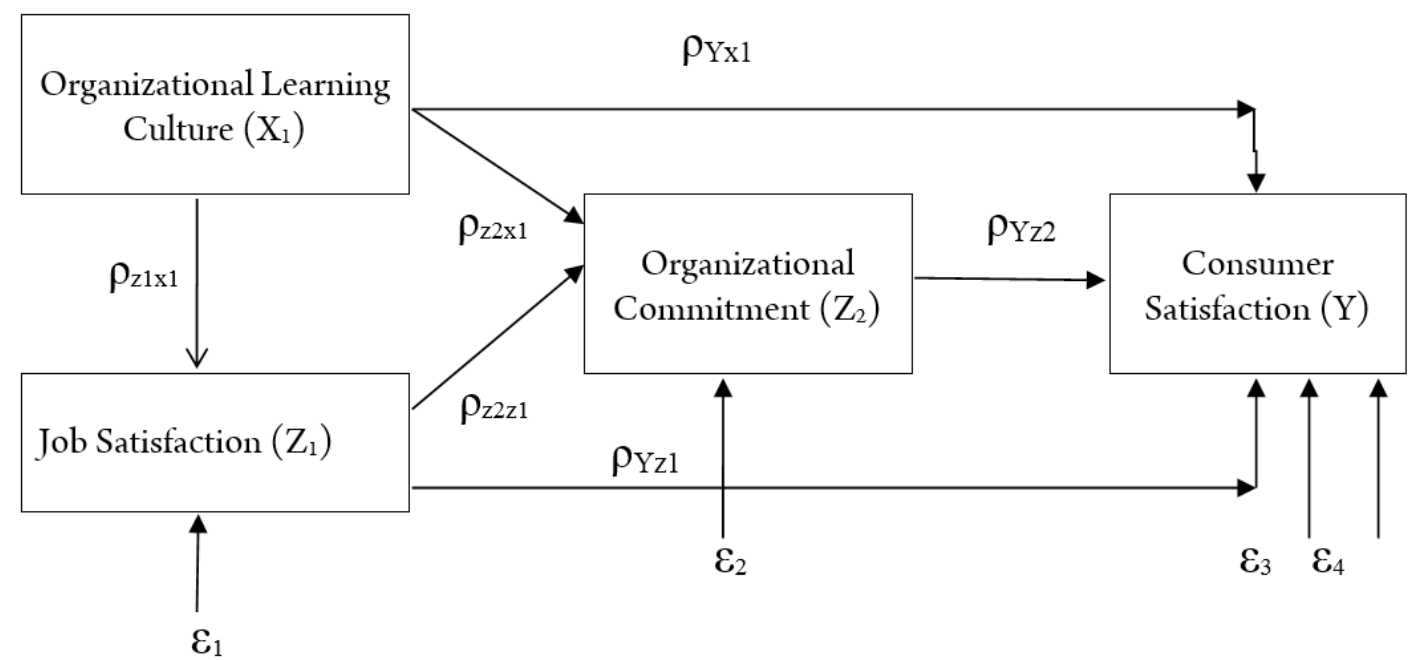

Figure 2. Path Diagram Model 
Audia Junita / Organizational Learning Culture, Consumer Satisfaction, and...

commitment became an important predictor of consumer satisfaction, affective commitment in particular. Based on that research, the fourth hypothesis is formulated as follow:

$\mathrm{H} 4$ : Organizational commitment affect significantly to consumer satisfaction

Hypothesis testing research is done to test the significant influence of organizational learning culture directly towards consumer satisfaction in the banking sector, as well as indirect influence through employee's attitude variables, include job satisfaction and organizational commitment as an intervening variable. Path diagram model can be seen in Figure 2.

\section{METHOD}

This research is causality study by using a quantitative approach. Population and sample of this study are the front liner employee's covers teller and customer service as well as the customer in 3 regional offices and 17 branch offices of Bank Syariah Mandiri in Medan Region. From the overall 20 business units of Syariah Mandiri Bank in Medan Region, determined 52 respondents of the entire front liner employee and 140 respondents represent the customers served by front liner, selected by using nonprobability sampling that is a quota and incidental sampling technique.

Bank Syariah Mandiri was chosen as a research location because it is one of the best performing banks in providing services to consumers. Employee's front line of Bank Mandiri Syariah in Medan region is choosen because aspects of worker attitudes become important variables in determining consumer satisfaction, consumer loyalty and bank competitive advantage (Heskett et al., 1997).

Employee perceptions, attitudes, and behaviors become interesting object characteristics because variability among individuals is possible over the interpretation of the same organizational policy. There is also a possibility of variability in the process of providing servi- ces to customers that will have a significant effect on retail banking performance (Frei et al., 1999). The competence of front-line banking personnel in maintaining personal relationships with customers has a significant effect on consumer perceptions of service quality (Gounaris et Al., 2003), consumer satisfaction and loyalty (Heskett et al., 1997) which will lead to the achievement of the organization's financial targets.

The variables in this study include Organizational Learning Culture $\left(X_{1}\right)$, Job Satisfaction $\left(\mathrm{Z}_{1}\right)$, Organizational Commitment $\left(\mathrm{Z}_{2}\right)$ and customer satisfaction $(\mathrm{Y})$, as measured by the interval scale on the 7-point Likert scale measurements. Organizational learning culture variables measured with Dimension Learning Organization Questionnaire (DLOQ) instruments developed by Watkins \& Marsick (1997) and Yang (2003), consists of 14 items from 7 dimensions include (1) creating continuous learning opportunities, (2) promoting inquiry and dialogue, (3) encouraging collaboration and team learning, (4) establishing systems to capture and share learning, (5) empowering people to have a collective vision , (6) connecting the organization to the environment, (7) using leaders who model and support learning at individual, team and he are organizational levels.

Job satisfaction variable is measured by the Job Diagnostic Survey (JDS) questionnaire built by Hackman \& Oldham (1975) with 2 items. Organizational commitment variable measured with instruments developed by Meyer \& Allen (1991) and Wang (2005) with 6 items from three dimensions, namely ( 1 ) the affective commitment, (2) normative commitment and (3) continuance commitment.

Consumer satisfaction variables over the quality of service received from the customer's Bank Syariah Mandiri front liner employees measured with 8 items of SERVQUAL instruments was developed by Parasuraman et al. (1988) with 5 dimensions namely (1) reliability, (2), responsiveness, (3) assurance, (4) empathy, and (5) tangible. However, this research negates the tangible dimension with a conside- 
ration that being measured is the services offered by the people (person).

Analysis technique which is used to answer the research hypothesis is path analysis. Path analysis is a technique for analyzing the causal relationship that occurs in multiple regressions if the independent variable (exogenous variable) influences dependent variable (endogen variable) not only directly but also indirectly (Sarwono, 2007). The steps of path analysis are as follows:

First, determine the hypothesis and structural equations. Second, create a path model is a diagram that connects between independent variables, intervening and dependent. Pattern relationship is shown by using arrows. Single arrows show a causal relationship between exogenous variables or intermediaries with one or more dependent variables. The arrows also connect the error (residual variable) with all endogenous variables respectively (Figure 2.)

Third, test assumptions of the research model, including normality, multicollinearity heteroscedasticity and linearity test (Ghozali, 2001). Fourth, test of hypothesis. Hypothesis $(\mathrm{Ha})$ is accepted if the probability value is $<0.05$, and vice versa Hypothesis $(\mathrm{Ha})$ is rejected if probability value $\geq 0.05$ (Ghozali, 2001).

Fifth, determine the path coefficients of the value of Standardized Coefficients Beta which shows the direct influence of an exogenous variable. Seventh, calculate the direct, indi- rect and total influences of exogenous variables on the endogenous variables.

\section{RESULT AND DISCUSSION}

\section{Result of Reliability and Validity Testing}

Results of reliability and validity test upon the research instrument that represents 14 items from the organizational learning culture variable, 2 items of job satisfaction variable and 8 items of consumer satisfaction variable proving that all the items are valid and reliable (Ghozali, 2001; Hair et al., 2006). However, from 6 items of organizational commitment variable tested, it is known that 2 items are not valid, so should be excluded from the analysis. Thus only 6 items are valid and reliable. The entire item is declared valid if it has the value of the corrected itemtotal correlation greater than 0.30 . The research variable is declared reliable if the value of Cronbach Alpha greater than 0.60 (Ghozali, 2001).

\section{Respondents' Characteristic by Demography}

The profile of employees as respondents is dominated by women (75.0\%), 21-30 years old $(51.0 \%)$, have relatively high education le$\operatorname{vel}(82.7 \%)$ as well as having a working period during $2-5$ years $(84.6 \%)$. While the profile of the customers as respondents are also dominated by women (50\%), high level of education $(32.7 \%)$, and age $21-30$ years $(37.7 \%)$ and have been a customer for less than 2 years (39.7\%).

Table 1. Hypothesis and Structural Equation

\begin{tabular}{|c|c|c|}
\hline No & Hypothesis & Structural Equation \\
\hline $\mathrm{H} 1$ & $\begin{array}{l}\text { Organizational learning culture affect significantly to } \\
\text { employee's job satisfaction }\end{array}$ & $\mathrm{Z}_{1}=\beta \mathrm{z}_{1} \cdot \mathrm{x}_{1} \mathrm{X}_{1}+\varepsilon_{1}$ \\
\hline $\mathrm{H} 2$ & $\begin{array}{l}\text { Organizational learning culture and job satisfaction } \\
\text { affect significantly to the organizational commit- } \\
\text { ment }\end{array}$ & $\mathrm{Z}_{2}=\beta \mathrm{z}_{2 \cdot \mathrm{xl}} \mathrm{X}_{1}+\beta \mathrm{z}_{2^{\prime} \cdot \mathrm{zl}} \mathrm{Z}_{1}+\varepsilon_{2}$ \\
\hline $\mathrm{H} 3$ & $\begin{array}{l}\text { Organizational learning culture and job satisfaction } \\
\text { of employees affect significantly to consumer satis- } \\
\text { faction }\end{array}$ & $\mathrm{Y}=\beta \mathrm{y} \cdot{ }_{\mathrm{x} 1} \mathrm{X}_{1}+\beta \mathrm{y} \cdot{ }_{\mathrm{z} 1} \mathrm{Z}_{1}+\varepsilon_{3}$ \\
\hline $\mathrm{H} 4$ & $\begin{array}{l}\text { Organizational commitment affect significantly to } \\
\text { consumer satisfaction }\end{array}$ & $\mathrm{Y}=\beta \mathrm{y}_{\mathrm{z}_{2}} \mathrm{Z}_{2}+\varepsilon_{4}$ \\
\hline
\end{tabular}


Audia Junita / Organizational Learning Culture, Consumer Satisfaction, and...

Description of Research Variable

In general, the organizations have a good organizational learning culture (98.4\%) with the value of the average (mean) of 5.8179, high levels of employee job satisfaction (98.1\%) with the value of the average (mean) of 5.6250. high level of organizational commitment (96.2\%) with the value of the average (mean) of 5.2548 and high level of consumer satisfaction (100\%) with the value of the average (mean) of 6.2056.

\section{Result of Path Analysis}

\section{Result of Model Assumptions Testing}

The assumption tests of research model include normality tests, multicollinearity, heteroscedasticity, and linearity. The normality test results prove that independent and dependent data are normally distributed. On each model are not found multicollinearity and there is no difference in variance of one observation residual to the others.

\section{Result of Hypothesis Testing}

The first hypothesis test results (H1) prove that organizational learning culture influence significantly to job satisfaction, with the signifi- cance value of that variable probability, is 0.000 $(\mathrm{p}<0.05)$ (see Table 2.)

The results of the second hypothesis which tests the influence of organizational learning culture and employee's job satisfaction towards organizational commitment prove that from both variables, only employee's job satisfaction variable that influences significantly to organizational commitment, with the significance values of variable probability is $0.002(\mathrm{p}<0.05)$. Organizational learning culture variable has no significant effect towards organizational commitment, with the significance values of variable probability is 0.995 ( $\mathrm{p} \geq 0.05)$ (see Table 3).

The third hypothesis test results of the influence organizational learning culture and job satisfaction towards customer satisfaction can be seen in Table 4 . The test results proved that the organizational learning culture and job satisfaction of employees do not affect significantly to consumer satisfaction. The significance value of variables probability are 0.124 and 0.104 (p $\geq 0.05$ ).

The fourth hypothesis test results related to the influence of organizational commitment towards customer satisfaction can be seen in

Table 2. Result of Organizational Learning Culture Towards Employee's Job Satisfaction Influence Test (H1)

Coefficients ${ }^{\mathrm{a}}$

\begin{tabular}{|c|c|c|c|c|c|}
\hline \multirow{2}{*}{ Model } & \multicolumn{2}{|c|}{ Unstandardized Coefficients } & \multirow{2}{*}{$\begin{array}{l}\text { Standardized Coefficients } \\
\text { Beta }\end{array}$} & \multirow{2}{*}{$\mathbf{t}$} & \multirow{2}{*}{ Sig } \\
\hline & B & Std. Error & & & \\
\hline (Constant) & 1.724 & 0.834 & & 2.067 & 0.044 \\
\hline Mean OLC & 0.670 & 0.142 & 0.555 & 4.716 & 0.000 \\
\hline
\end{tabular}

a. Dependent Variable: Mean JS

Table 3. Result of Organizational Learning Culture and Employee's Job Satisfaction towards Organizational Commitment Influence Test (H2)

Coefficients ${ }^{\mathrm{a}}$

\begin{tabular}{|c|c|c|c|c|c|}
\hline \multirow{2}{*}{ Model } & \multicolumn{2}{|c|}{ Unstandardized Coefficients } & \multirow{2}{*}{$\begin{array}{l}\text { Standardized Coefficients } \\
\text { Beta }\end{array}$} & \multirow{2}{*}{$\mathbf{t}$} & \multirow{2}{*}{ Sig } \\
\hline & B & Std. Error & & & \\
\hline (Constant) & 1.814 & 1.128 & & 1.608 & 0.114 \\
\hline Mean OLC & 0.001 & 0.222 & 0.000 & 0.006 & 0.995 \\
\hline Mean JS & 0.613 & 0.184 & 0.498 & 3.341 & 0.002 \\
\hline
\end{tabular}

a. Dependent Variable: Mean OC after the Invalid Item is Droped 
Table 5. Organizational commitment influence significantly to consumer satisfaction, with the significance value of variable probability is $0.043(\mathrm{p}<0.05)$.

\section{The Result of Path Coefficient}

Based on the results of the fourth research hypotheses, then the empirical path diagram can be seen in Figure 3.

\section{The Result of Determination Coefficient and}

\section{Model Residual Value}

The determination coefficient is a coefficient that refers to the extent of influence or contribution of exogenous variables to endogenous variables. Based on the results of hypothesis testing on the research model, obtained the calculation of the coefficient of determination and residual value of the research model as follows (see Table 6).

Result of Standardized Direct, Indirect and Total Effect from Exogenous on Endogen Variables

The result of path analysis shows that organizational learning culture significantly does not directly influence consumer satisfaction, but indirectly significant influence through employee attitude variable include job satis-

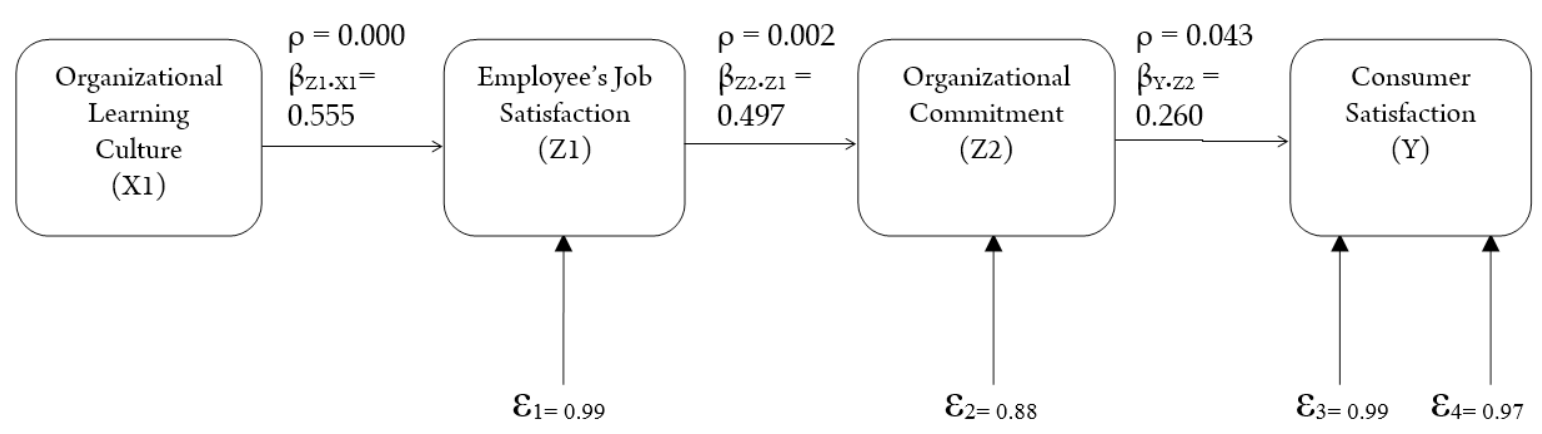

Figure 3. Result of Path Analysis

Table 4. Result of Organizational Learning Culture and Employee's Job Satisfaction towards Customer Satisfaction Influence Test (H3)

Coefficients $^{\mathrm{a}}$

\begin{tabular}{llllll}
\hline \multirow{2}{*}{ Model } & \multicolumn{2}{l}{ Unstandardized Coefficients } & \multicolumn{2}{l}{ Standardized Coefficients } & \multirow{2}{*}{ t } \\
\cline { 2 - 4 } & B & Std. Error & Beta & 11.581 & 0.000 \\
\hline 1 (Constant) & 6.060 & 0.523 & & 1.567 & 0.124 \\
Mean OLC & 0.161 & 0.103 & 0.260 & 1.655 & 0.104 \\
Mean JS & 0.141 & 0.085 & 0.275 & \\
\hline
\end{tabular}

a. Dependent Variable: Mean of Customer Satisfaction

Table 5. Result of Organizational Commitment Towards Customer Satisfaction Influence Test (H4)

\begin{tabular}{llllll}
\hline \multirow{2}{*}{ Model } & \multicolumn{2}{l}{$\begin{array}{l}\text { Unstandardized } \\
\text { Coefficients }\end{array}$} & $\begin{array}{l}\text { Standardized } \\
\text { Coefficients }\end{array}$ & \multirow{2}{*}{ t } & \multirow{2}{*}{ Sig } \\
\cline { 2 - 4 } & B & Std. Error & Beta & & \\
\hline $1 \quad$ (Constant) & 6.774 & 0.305 & & 22.175 & 0.000 \\
$\begin{array}{l}\text { Mean OC After The In- } \\
\text { valid Item is Thrown }\end{array}$ & 0.108 & 0.057 & 0.260 & 1.903 & 0.043 \\
\hline
\end{tabular}

a. Dependent Variable: Mean Consumer Satisfaction 
Audia Junita / Organizational Learning Culture, Consumer Satisfaction, and...

faction and organizational commitment. The amount of indirect influence as well as the total influence of organizational learning culture through job satisfaction variable and organizational commitment is $\beta \mathrm{Z} 1$.X1 $\mathrm{x} \beta \mathrm{Z} 2 . \mathrm{Z} 1 \times \mathrm{XY} . \mathrm{Z2}$ $=(0.555) \times(0.497) \times(0.260)=0.0717$. Details of the calculation can be seen in Table 7 .

Therefore, the empirical tests results are consistent with the conclusions of empirical research conducted by Coats (2015). He states that the organizational learning culture is not granted directly able to affect organizational performance, such as consumer satisfaction. A study related to organizational learning culture must be understood in relation to the various organization's variables and attributes (Cho, 2009), like employee's attitude such as job satisfaction and organizational commitment.

The relationship between organizational learning culture, job satisfaction, and organizational commitment is validated empirically through the results of this research. Organizational learning culture through job satisfaction did not contribute directly in eliciting consumer satisfaction. These results contrast with the results of (Pantouvakis \& Bouranta, 2013) and (Malike, 2016) research. Similarly, the organizational learning culture through organizational commitment has no effect significantly to con-

Table 6. Determination Coefficient and Residual Value of Research Model

\begin{tabular}{|c|c|c|c|c|}
\hline Hypothesis & Research Model & $\begin{array}{l}\text { Determination } \\
\text { (Adjusted R2) }\end{array}$ & Coefficient & $\begin{array}{l}\text { Residual Value } \\
(\varepsilon)\end{array}$ \\
\hline $\mathrm{H} 1$ & $\mathrm{Z}_{1}=\beta \mathrm{z}_{1} \cdot \mathrm{x}_{1} \mathrm{X}_{1}+\varepsilon_{1}$ & 0.026 & & 0.99 \\
\hline $\mathrm{H} 2$ & $Z_{2}=\beta z_{2} \cdot{ }_{1} X_{1}+\beta z_{2} \cdot z_{1} Z_{1}+\varepsilon_{2}$ & 0.217 & & 0.88 \\
\hline $\mathrm{H} 3$ & $\mathrm{Y}=\beta \mathrm{y} \cdot \mathrm{x}_{\mathrm{X}} \mathrm{X}_{1}+\beta \mathrm{y} \cdot \mathrm{z}_{\mathrm{Z1}} \mathrm{Z}_{1}+\varepsilon_{3}$ & 0.026 & & 0.99 \\
\hline $\mathrm{H} 4$ & $\mathrm{Y}=\beta \mathrm{y} \cdot{ }_{\mathrm{zz}} \mathrm{Z}_{2}+\varepsilon_{4}$ & 0.049 & & 0.97 \\
\hline
\end{tabular}

Table 7. Standardized Direct Effects, Standardized Indirect Effects and Standardized Total Effects

\begin{tabular}{|c|c|c|c|}
\hline \multirow{4}{*}{$\begin{array}{l}\text { Standardized } \\
\text { Direct Effect }\end{array}$} & & $\begin{array}{l}\text { Organizational } \\
\text { Learning Culture }(\mathrm{X})\end{array}$ & $\begin{array}{l}\text { Consumer } \\
\text { Satisfaction (Y) }\end{array}$ \\
\hline & $\begin{array}{l}\text { Consumer } \\
\text { Satisfaction }(\mathrm{Y})\end{array}$ & 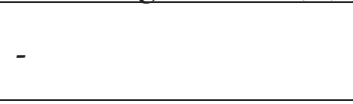 & 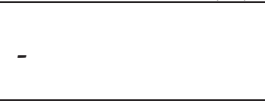 \\
\hline & $\begin{array}{l}\text { Job } \\
\text { Satisfaction }(\mathrm{Z} 1)\end{array}$ & 0.555 & - \\
\hline & $\begin{array}{l}\text { Organizational Commitment } \\
\text { (Z2) }\end{array}$ & - & 0.260 \\
\hline \multirow{3}{*}{$\begin{array}{l}\text { Standardized } \\
\text { Indirect Effect }\end{array}$} & $\begin{array}{l}\text { Consumer } \\
\text { Satisfaction (Y) }\end{array}$ & 0.071 & - \\
\hline & $\begin{array}{l}\text { Job } \\
\text { Satisfaction }(\mathrm{Z1})\end{array}$ & - & 0.132 \\
\hline & $\begin{array}{l}\text { Organizational Commitment } \\
(\mathrm{Z} 2)\end{array}$ & 0.275 & - \\
\hline \multirow{3}{*}{$\begin{array}{l}\text { Standardized } \\
\text { Total Effect }\end{array}$} & $\begin{array}{l}\text { Consumer } \\
\text { Satisfaction (Y) }\end{array}$ & 0.071 & - \\
\hline & $\begin{array}{l}\text { Job } \\
\text { Satisfaction }(\mathrm{Z} 1)\end{array}$ & 0.555 & 0.132 \\
\hline & $\begin{array}{l}\text { Organizational Commitment } \\
\text { (Z2) }\end{array}$ & 0.275 & 0.260 \\
\hline
\end{tabular}


sumer satisfaction. These results contrast with the research that has been done by (Islam et al., 2014a).

Organizational learning culture influence significantly and indirectly towards customer satisfaction, through integrated employee's attitude, include job satisfaction and organizational commitment. Thus the results of this study are consistent with previous empirical studies which prove that organizational learning culture influences significantly to employee's job satisfaction (Lund, 2003). However, job satisfaction does not affect significantly to consumer satisfaction.

This is in line with the results of Barnes (2015) which concluded that among employees who are satisfied and the level of customer satisfaction, there is no significant effect. Satisfied employees will lead to a high commitment of organizational and customers (Amoopour et al., 2001). Therefore, job satisfaction variable serves as the intervening variable between organizational learning culture and organizational commitment (Wang, 2005; Hsu, 2009; Islam et al., 2014b).

Furthermore, employees who have high organizational commitment will affect the emergence of consumer satisfaction. This is in tune with results research of ( $\mathrm{He}$ et al., 2011; Islam et al., 2014a; Murale et al., 2015) which prove that organizational commitment became an important predictor of consumer satisfaction

The results of this research are also in line with the concept of causal relationships between job satisfaction, organizational commitment, and the service efforts. Job satisfaction is the antecedent for organizational commitment which will then affect the service efforts of the organization's member (Testa, 2001). Job satisfaction represents individual assessment over a variety of things that exist in the work environment (preselection process), the results will come out in the form of emotional response.

If the individual has a positive appraisal of various aspects of the work environment then the emotional response will appear in the form of organizational commitment. The result of the organizational commitment in the form of coping intention is used to achieve the desired results such as hard working to satisfy a need/ desire of consumers (service efforts) (Testa, 2001).

The dimension of interactions between people and situations (person-situation interaction) are making the same stimulus will react differently through the process of individual cognition. Every situation is seen different and when that situation is perceived through an individual cognition process, then will lead to affective and behavioral differences. Therefore, the individual is not static, acting equally in all circumstances, but the individual is flexible and always changing, giving a response to the interaction itself and the situation they are facing of (Luthans, 2011). Schulte et al. (2009) confirm that the employee's attitudes are largely determined by how the perception of employees against work environment as a whole.

Based on the influence results test of organizational learning culture directly towards consumer satisfaction and indirectly through job satisfaction and organizational commitment, can be concluded that organizational learning culture significantly influences to consumer satisfaction through integrated employee's attitudes i.e. job satisfaction and organizational commitment as an intervening variables.

\section{CONCLUSION AND RECOMMENDATION}

The role of attitude as the predisposition of an individual's behavior, attracting a lot of attention to academics in the field of management science, especially organizational behavior. Through this research, the role of attitude in mediating the influence of organizational learning culture to worker's service behavior, in order to create consumer satisfaction in the banking sector, proven empirically. Organizations that have a good organizational learning culture will be able to engender a positive attitude in employees, including job satisfaction and organizational commitment. Organizational learning culture did not contribute directly to- 
Audia Junita / Organizational Learning Culture, Consumer Satisfaction, and...

wards consumer satisfaction, but the significant influence will be visible through the employee job satisfaction and organizational commitment as the intervening variables.

It needs further study involving consumers as respondents in larger quantities to provide the generalization of organizational learning culture impact towards employee's attitude and consumer satisfaction. Advanced research by adding some context to the relationship between organizational learning culture and organizational performance also needs to be explored, to understand the complexities that might occur. Finally, because the organizations and practice of learning they are always changing, the longitudinal studies of one or a few companies can provide valuable insight into how the learning organization, employee's attitudes, and other variables interact along the time.

\section{REFERENCES}

Amoopour, M., Hemmatpour, M \& Mirtaslimi, Seyed, S. 2001. Job Satisfaction of Employee and Customer Satisfaction. Arabian Journal of Business and Management Review (Oman Chapter). Sohar3 (6): 1-6.

Barnes, A. L. 2015. Relationship Between Job Satisfactiontaff and Patient Satisfaction: Evidence from Community Health Centers in South Carolina. Dissertations, University of South Carolina.

Bates, R \& Khasawneh, S. 2005. Organizational Learning Culture, Learning Transfer Climate and Perceived Innovation in Jordanian Organizations. International Journal of Training and Development. 9 (2): 96-109.

Blanchard, R. F \& Galloway, R. L. 1994. Quality in Retail Banking. International Journal of Service Industry Management. 5 (4): 5-23.

Cerne, M., Jaklic, M., Skerlavaj, M., Aydinlik, A. Ü \& Polat, D. D. 2012. Organizational Learning Culture and Innovativeness in Turkish Firms. Journal of Management and Organization. 18 (2): 193-219.

Chaundry, M. A \& Shah, N. 2007. Impact of Supportive Leadership and Organizational Learning Culture as A Moderator on The Relationship of Psychological Empowerment and Organizational Commitment. Journal of Business Strategies. 5 (1):39-50.

Cho, I. 2009. Exploring The Relationship Between Dimensions of Organizational Learning and Firm's Financial and Knowledge Performance in The Korean Business Context. Dissertations. University of Illinois.

Cirone, J. D. 2003. The Service Profit Chain Viewed in an Educational Domain: Is there a Correlation Between Faculty Commitment and Student Satisfaction? Dissertation, Nova Southeastern University.

Coats, J. R. 2015. A Comparison of Organizational Performance in Publicly Traded Companies With and Without a Mature Organizational Learning Culture. Dissertations. Capella University.

Coskun, A \& Frohlich, C. L. 1992. Service: The Competitive Edge in Banking. The Journal of Services Marketing. 16 (1): 15-22.

Cunningham, J. B \& Gerard, P. 2000. Characteristics of Well-Performing Organizations in Singapore. Singapore Management Review. 22 (1): 35-64.

Dirani, K. M. 2007. The Relationship Among Learning Organization Culture, Job Satisfaction, and Organizational Commitment in The Lebanese Banking Sector and The Effect of Social Patterns as Moderator Variables. Dissertation. University of Illinois.

Fecikova, I. 2004. An Index Method for Measurement of Customer Satisfaction. TQM Magazine.16: 57-66.

Frei, F. X., Kalakota, R., Leone, A. J \& Marx, L. M. 1999. Process Variation As a Determinant of Bank Performance: Evidence from the Retail Banking Study. Management Science, 45 (9) Performance of Financial Institutions): 1210-1220.

Freiling, J \& Fichtner, H. 2010. Organizational Culture as the Glue between People and Organization: A Competence-based View on Learning and Competence Building. Zeitschrift Für Personalforschung. 24 (2): 152-172.

Fuentes, S. C. G. 2008. The Link Between Learning Culture and Organizational Performance in Organizations Using the Balanced Scorecard. Dissertation. The University of New Mexico.

Ghozali, I. 2001. Aplikasi Analisis Multivariate Dengan Program SPSS. Semarang: Badan Penerbit Universitas Diponegoro. 
Goh, S. C \& Ryan, P. J. 2008. The Organizational Performance of Learning Companies: A Longitudinal and Competitor Analysis Using Market and Accounting Financial Data. The Learning Organization. 15 (3): 225-239.

Gounaris, S. P., Stathakopoulos, V \& Athanassopoulos, A. D. 2003. Antecedents to Perceived Service Quality: An Exploratory Study in The Banking Industry. The International Journal of Bank Marketing. 21 (4/5): 828-853.

Hackman, J. R. \& Oldham, G. R. 1975. Development of The Job Diagnostic Survey. Journal of Applied Psychology. 60: 159-170.

Hair, J. F. J., Anderson, R. E., Tatham, R. L \& Black, W. C. 2006. Multivariate Data Analysis. (3rded.). New Jersey: Prentice-Hall Inc.

Harris, L. 2002. The Learning Organisation--Myth or Reality? Examples from The UK Retail Banking Industry. The Learning Organization. 9 (2): 78-88.

Harris, S. G \& Mossholder, K. W. 1996. The Affective Implications of Perceived Congruence With Cultural Dimensions During Organizational Transformation. Journal of Management. 22 (4): 525-45.

He, Y., Li, W \& Lai, K. K. 2011. Service Climate, Employee Commitment, and Customer Satisfaction. International Journal of Contemporary Hospitality Management. Bradford 2 (5): 592-607.

Heskett, J.L., Jones, T.O., Lovemann, G.W., Sasser, W. E \& Schlesinger, L. A. 1994. Putting The Service-Profit Chain to Work. Harvard Business Review. 72 (2): 164-74.

Heskett, J. L., Sasser, W. E \& Schlesinger, L. 1997. The Service Profit Chain. New York, NY: Free Press.

Holland, J. 2010. Banks, Knowledge, and Crisis: a Case of Knowledge and Learning Failure. Journal of Financial Regulation and Compliance. 18 (2): 87-105.

Hsu, H.-Y. 2009. Organizational Learning Culture's Influence on Job Satisfaction, Organizational Commitment, and Turnover Intention among R\&D Professionals in Taiwan during an Economic Downturn. Dissertation, University of Minnesota.

Islam, T., Khan, S. ur R \& Ungku Norulkamar Ungku Bt. Ahmad; Ahmed, I. 2013. Organizational Learning Culture and Leader-Member Exchange Quality: The Way to Enhance
Organizational Commitment and Reduce Turnover Intentions. The Learning Organization. 20 (4/5): 322-337.

Islam, T., Ahmad Kassim, N., Ali, G \& Sadiq, M. 2014a. Organizational Learning Culture and Customer Satisfaction: The Mediating Role of Normative Commitment. The Learning Organization. 2 (6): 404-392.

Islam,Talat, Khan, S. U. R., Norulkamar Bt. Ungku Ahmad, U., Ali, G \& Ahmed, I. 2014b. Organizational Learning Culture and Psychological Empowerment as Antecedents of Employee's Job-Related Attitudes: a Mediation Model. Journal of Asia Business Studies. 8 (3): 249-263.

Joo, B.-K \& Park, S. 2010. Career Satisfaction, Organizational Commitment, and Turnover Intention: The Effects of Goal Orientation, Organizational Learning Culture, and Developmental Feedback. Leadership \& Organization Development Journal. 3 (6): 482-500.

Kermani, Z. Z. 2013. A Study of the Linking Between Job Satisfaction and Customer Satisfaction: A Case Study of Iran Insurance; Kerman; Iran. Journal of Marketing Development and Competitiveness, West Palm (4): 104-109.

Lin, Y.-Y. 2006. An Examination of the Relationships Between Organizational Learning Culture, Structure, Organizational Innovativeness and Effectiveness: Evidence From Taiwanese Organizations. Dissertation, University of Minnesota.

Lund, D. B. 2003. Organizational Culture and Job Satisfaction. Journal of Business and Industrial Marketing. 18 (3): 219-236.

Luthans, F. 2011. Organizational Behavior: An Evidence-Based Approach. New York: The McGraw-Hill Companies, Inc.

Maalik, M \& Khan, T. H. 2011. Impact of Organizational Context on Key Determinant of Customer Satisfaction In Baking Sector of Pakistan. Interdisciplinary Journal of Contemporary Research in Business. 3 (2): 1055-1068.

Malik, M. E \& Danish, R. Q. 2010. Impact of Motivation to Learn and Job Attitudes on Organizational Learning Culture in a Public Service Organization of Pakistan. South Asian Studies. 25 (2): 217-235.

Malike, A. 2016. Examining the Relationship between Organizational Learning Culture, and 
Audia Junita / Organizational Learning Culture, Consumer Satisfaction, and...

Customer Satisfaction in Insurance Industry. European Online Journal of Natural and Social Sciences. 5 (3): 647-663.

Marsick, V. J. 1998. Transformative Learning from Experience in the Knowledge Era. (4).: 119136.

Meyer, J. P \& Allen, N. J. 1991. A Three-Component Conceptualization of Organizational Commitment. Human Resource Management Review. 1: 61-89.

Miller, S. C. 2015. Individual Readiness for Change: The Impact of Organizational Learning Culture and Learning Motivation. Dissertation, Regent University.

Misbach, I., Surachman \& Hadiwidjojo, D. A. 2013. Islamic Bank Service Quality and Trust: Study on Islamic Bank in Makassar Indonesia. International Journal of Business and Management. 8 (5): 48-61.

Murale, V., Singh, J \& Preetha, R. 2015. Employee Commitment and Patient Satisfaction: An Initial Reflection from Indian Healthcare Sector. International Journal of Customer Relations. 3 (1): 22-30.

Namwong, Kantheera, Jhundra-indra, Prathanporn, Raksong, S. 2015. Dynamic Organizational Learning Strategy and Firm Survival: A Conceptual Model. In Proceedings, The Academy of Organizational Culture, Communications and Conflict. 20: 12-25.

Pantouvakis, A \& Bouranta, N. 2013. The Link Between Organizational Learning Culture and Customer Satisfaction: Confirming Relationship and Exploring Moderating Effect. The Learning Organization. 20 (1): 48-64.

Parasuraman, A., Zeithaml, V. A \& Berry, L. L. 1988. SERVQUAL: A Multiple-Item Scale for Measuring Consumer Perceptions of Service Quality. Journal of Retailing, 64 (1): 12-40.

Park, S. 2011. The Impact of Organizational Learning Culture, Goal Orientation, Managerial Effectiveness, and Psychological Empowerment on Employee's Workplace Learning. Dissertations, University of Minnesota.

Permana, M. V. 2013. Peningkatan Kepuasan Pelanggan Melalui Kualitas Produk Dan Kualitas Layanan. Jurnal Dinamika Manajemen. 4 (2): 115-131.

Porter, M. E. 1985. Competitive Advantage. New York: The Free Press.

Sabir, H. M \& Kalyar, M. N. 2013. Firm's Innovative- ness and Employee Job Satisfaction: The Role of Organizational Learning Culture. Interdisciplinary Journal Of Contemporary Research in Business. 4 (9): 670-686.

Sabri, P. S. U., Ilyas, M \& Amjad, Z. 2015. Organizational Learning Culture and its Effects on Critical Thinking Skills on Female Teachers of Public Sector HEI. Bulletin of Education and Research. 37. (2) Dec 2015: n/a.

Sakapurnama, Eko, Kusumastuti, R. 2013. The Development of Online Banking System in Indonesia, Implication in Human Resources Management Strategy. Advances in Management \& Applied Economics. 3 (2): 123-134.

Santoso, E. 2011. Intellectual Capital in Indonesia: The Influence on Financial Performance of Banking Industry. Dissertations, University of Phoenix.

Sarwono, J. 2007. Analisis Jalur untuk Riset Bisnis dengan SPSS. Yogyakarta: Andi Offset.

Schein, E. 1996. Culture: The Missing Concept in Organization Studies. Administrative Science Quarterly.41:229-40.

Schlesinger, L. A \& Heskett, J. L. 1991. Customer Satisfaction is Rooted in Employee Satisfaction. Harvard Business Review, NovemberDecember: 149-81.

Schulte, M., Ostroff, C., Shmulyian, S \& Kinicki, A. 2009. Organizational Climate Configurations: Relationships to Collective Attitudes, Customer Satisfaction, and Financial Performance. Journal of Applied Psychology. 94 (3): 618-634.

Senge, P. M. 1990. The Fifth Discipline: The Art and Practice of The Learning Organization. New York: Doubleday/ Currency.

Snipes, R. L., Oswald, S. L., LaTour, M \& Armenakis, A. A. 2005. The Effects of Specific Job Satisfaction Facets on Customer Perceptions of Service Quality: an Employee-Level Analysis. Journal of Business Research. 58: 1330-1339.

Tanisah \& Maftuhah, I. 2015. The Effects Of Service Quality, Customer Satisfaction, Trust, And Perceived Value Towards Customer Loyalty. Jurnal Dinamika Manajemen. 6 (1): 55-61.

Testa, M. R. 2001. Organizational Commitment, Job Satisfaction, and Effort in The Service Environment. The Journal of Psychology. 135 (2): 226-236. 
Thompson, M. A. 2000. The Relationship Between Organizational Learning Cultures and Participation in Decision Making. Dissertation. Georgia State University.

Toelle, S. 2006. The Linkages Among Service Quality Attributes, Customer Value, Customer Satisfaction and Customer Loyalty in Indonesia Retail Banking. Dissertations, Nova Southeastern University.

Utami, B. B \& Wartini. 2015. Pengaruh Inovasi Layanan Terhadap Loyalitas Pelanggan Dengan Kepuasan Pelanggan Sebagai Variabel Intervening. Management Analysis Journal. 4 (3): 229-235.

Vilares, M. J \& Coelho, P. S. 2003. The EmployeeCustomer Satisfaction Chain in The ECSI Model. European Journal of Marketing. 37 (11/12): 1703-22.

Wang, X. 2005. Relationships Among Organizational Learning Culture, Job Satisfaction, and Organizational Commitment in Chinese State-owned and Privately-owned Enterprises. Dissertation, University of Minnesota.

Watkins, K. E \& Marsick, V. J. 1997. Dimensions of The Learning Organization Questionnaire [Survey]. Warwick, RI: Partners for the Learning Organization.

Xie, D. 2005. Exploring Organizational Learning Culture, Job Satisfaction, Motivation to Learn, Organizational Commitment and Internal Service Quality in Sport Organization, Dissertation.The Ohio State University.

Yang-Lim, L. 2004. Customer Service and Organizational Learning in The Context of Strategic Marketing. Marketing Intelligence and Planning. 22 (6): 652-662.

Yang, B. 2003. Identifying Valid and Reliable Measures for Dimensions of a Learning Culture. Advances in Developing Human Resources. 5 (2): $152-162$. 